補緅誌, J Jpn Prosthodont Soc, $43: 849 \sim 856,1999$.

\title{
原著論文
}

\section{鋳接および熱処理が磁性アタッチメントの キーパーに及ぼす影響について}

中村 和夫 小竹 雅人 水谷 紘 植野 良子藍稔

Effects of Casting and Heat Treatments on Magnetic Keepers

Kazuo Nakamura, Masato Kotake, Hiroshi Mizutani, Ryoko Ueno and Minoru Ai

\begin{abstract}
It has been pointed out that properties of the magnetic keeper may change from original condition after casting. In this study, to evaluate the effect of the casting and the heat treatments for the casting alloy on the property of the keeper, hardness test and light microscopic observation were carried out.

Two kinds of keepers (HICOREX Slim, Hitachi Metals, Japan and Magfit 600, Aichi Steel, Japan) were investigated in this study. These keepers were cast on with gold-silver-palladium alloy (Castwell MC, GC, Japan). Then homogenization heat treatment and hardening heat treatment for gold-silver-palladium alloy were performed on the casting-on specimens. After casting-on and each heat treatment, hardness test and microscopic observation on the keepers were performed. Before these experiments, non-heated keepers were estimated as control.

The results for casting-on samples showed a decrease in hardness for both keepers. Furthermore, after each heat treatment, a decrease in hardness was found as compared to the control for both keepers $(p<0.01$, ANOVA).

In both keepers, microscopic findings showed that grains became larger than those of control and grain boundaries became distinguished.

The results showed that heat treatments for the casting alloy should be avoided because the properties of keepers were adversely affected.
\end{abstract}

Key words : magnetic attachment, heat treatment, casting-on

\section{I. 緒 言}

磁性アタッチメントのキーパーは，現在ほとんどが歯科 用合金と鋳接して使用されている1 3). しかしながら，鋳 接過程がキーパー材に及ほすす影響については不明な点も多 い。キーパーに使用されているステンレス合金に関して は，鋳接過程におけるリングの係留や鋳造温度に相当する 加熱にさらされた場合に，硬さ等の機械的性質や耐食性に

東京医科歯科大学歯学部歯科補綴学第 1 講座（主任：藍 稔教授） The First Department of Prosthodontics, Faculty of Dentistry, Tokyo Medical and Dental University (Chief : Prof. Minoru $\mathrm{Ai})$

平成 11 年 4 月 5 日受付
影響が及ぶ可能性のあることが指摘されている，磁性ア タッチメントは, 磁石構造体の吸着面とキーパーの間にわ ずかな隙間が生じても吸引力に及ほす影響が大きい. 鋳接 による加熱でキーパーの硬さが加熱前，すなわち磁石構造 体の吸着面のステンレス鋼の硬さと異なってしまった場合 には, 長期間の使用の結果いずれかが摩耗して平滑性が損 なわれ，吸引力の低下を招く可能性がある。これまで，鋳 接過程でキーパー材の理工学的性質に及ほす因子として, 埋没材の種類あるいは加熱係留温度, 係留時間がキーパー の酸化被膜厚さに及ほす影響について報告され, 高い係留 温度や長い係留時間は酸化被膜厚さが増大することや埋没 材の種類により形成される酸化被膜厚さが異なることが報 告されている ${ }^{4,5)}$. また, キーパーを短時間加熱した後の 
表 1 Compositions of magnetic keepers used in this investigation 使用キーパーならびにその組成

\begin{tabular}{lcccccc}
\hline \hline キーパー & $\mathrm{Fe}(\%)$ & $\mathrm{Cr}(\%)$ & $\mathrm{Mo}(\%)$ & その他 $(\%)$ & 口ット番号 & メーカー \\
\hline ハイコレックススリムキーパー & $>67$ & 30 & 2 & $<1$ & 704015 & 日立金属 \\
マグフィット600キーパー & $>78$ & 19 & 2 & $<1$ & $01086 \mathrm{E}$ & 愛知製鋼 \\
\hline
\end{tabular}

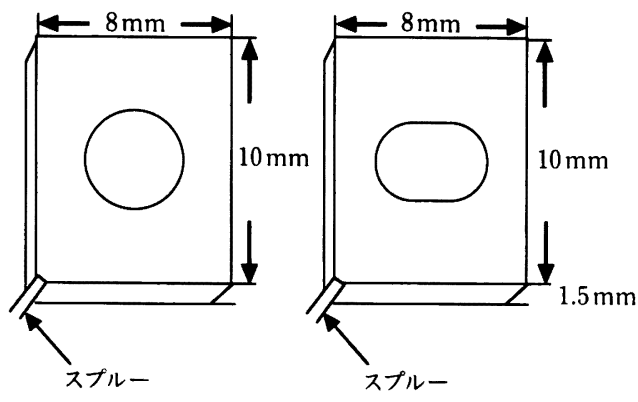

国 1 Specimens shape used for the study 鋳接試料の模式図

左：ハイコレックススリムキーパー

右：マグフィット 600 キーパー

キーパーの硬さに対する検討では, SUS $447 \mathrm{~J} 1$ ステンレ ス鋼を用いたキーパーで硬さの減少が報告されている6). しかし，実際に鋳接された試料に関する検討は行われてい ない.さらに，鋳接に用いられることの多い金合金や $12 \%$ 金銀パラジウム合金は, 一般に硬化熱処理を行った 状態で用いられているが，これらの熱処理に伴う繰り返し 加熱の影響に関しても明らかではない.そこで，実際に キーパーの鋳接ならびに鋳接合金に対する種々の熱処理を 行い, これらの加熱がキーパーの硬さならびに結晶粒度に どのような影響を及ほすかについて検討した。

\section{II. 材料および方法}

本研究には 2 種類の磁性アタッチメント用キーパーを使 用し，それぞれに対して鋳接過程では最終係留温度を 3 条 件，さらに鋳接試料に対して熱処理を 3 条件設定し，それ らがキーパーならびに鋳接合金の硬さに及ほす影響を検討 した。また，キーパーについては結晶粒度の観察も行っ た.

\section{1. 材料}

1）磁性アタッチメント用キーパー

本研究で使用したキーパーはハイコレックススリム 4013 キーパー（日立金属（株））およびマグフィット 600 キーパー（愛知製鋼（株））であり，それぞれの組成を表 1 に示す。

いずれもロット番号の揃っているものを用いた。

2）埋没材ならびに鋳接合金

使用した埋没材は従来型石高系埋没材（クリストバライ
表 2 Heat treatments for gold-silver-palladium alloy $12 \%$ 金銀パラジウム合金に対する熱処理条件

\begin{tabular}{lc}
\hline \hline 熱処理 & 処理条件 \\
\hline 溶体化処理 & $700^{\circ} \mathrm{C}$ て 5 分間加熱後水中急冷 \\
硬化熱処理 & 溶体化処理後 $400^{\circ} \mathrm{C} て ゙ 15$ 分間加熱後, 室温にて放冷 \\
\hline
\end{tabular}

卜, 松風）である. 混水比はメーカー指示に従い, 手練和 30 秒間の後に真空練和 30 秒間 (Vac-vester, Whip-Mix) とした．鋳接合金には $12 \%$ 金銀パラジウム合金（キャス

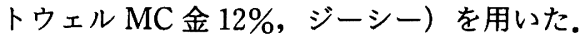

\section{2. 方法}

1）ワックスパターン

インレーワックス（インレーワックス・ミディアム， ジーシー）を $10 \mathrm{~mm} \times 8 \mathrm{~mm} \times 1.5 \mathrm{~mm}$ の板状に整形し, その中央にキーパー上面とワックス上面が一致するように キーパーを固定したパターンを製作し，これを $12 \%$ 金銀 パラジウム合金で鋳造して鋳接試料とした（図 1).

ワックスパターンは水を含ませた厚さ $0.7 \mathrm{~mm}$ のリング ライナー(ニューキャスティングライナーNo. 3, ジー シー）を 1 枚裏層した $30 \phi \times 55 \mathrm{~mm}$ の鋳造リングの中央 に各 1 個埋没した。

2）リングの加熱，係留および鋳接

鋳接にあたり，鋳造リングの最終係留温度の違いにより $600,700,800^{\circ} \mathrm{C}$ の 3 グループに分けた. リングは埋没後 1 時間乾燥させ $200,400^{\circ} \mathrm{C}$ の電気炉内で各 30 分間係留 し，上記の最終係留温度で 1 時間係留の後に鋳造した。鋳 造体は室温まで放冷後埋没材から取り出し，超音波洗浄を 行い酸処理は行わなかった.

3） $12 \%$ 金銀パラジウム合金に対する熱処理

鋳接試料について $12 \%$ 金銀パラジウム合金に対する熱 処理の影響を検討するため, アズキャストの状態のほかに 溶体化処理および硬化熱処理を行った試料を製作した。熱 処理は表 2 に示すメーカー指示の条件を用いた。

鋳接試料はそれぞれのキーパーに対し，上記の実験条件 のそれぞれの組合せごとに 8 個ずつ製作し，そのうち 5 個 を硬さ測定に，残る 3 個を結晶粒度の観察に使用した。

4）硬さ測定

鋳接試料は自動研磨機 ECOMET 3 (Buehler) を用い て\# 340，\# 400，\#600の SiC 紙研磨， $0.05 \mu \mathrm{m}$ のアルミ ナによるバフ研磨を行ったのち，マイクロビッカース硬度 計 NT-M 001 （島津製作所）を用い, 荷重 $200 \mathrm{gf}, 15$ 秒 
間負荷で硬さの測定を行った．硬さ測定はキーパーに対し てはその中央部で，鋳接合金に対しては鋳接試料の短辺と キーパー界面の中間部で行い, 3 点の測定データの平均值 をもって硬さの值とした. 硬さ測定のコントロールには, 製品である未加工のキーパーと金銀パラジウム合金イン ゴットを用いた。

最終係留温度条件の違いと熱処理条件の違いがキーパー の硬さに及ほす影響について二元配置分散分析を行った。 さらに, post-hoc test として Scheffe's F 法を用いて多重 比較検定を行った。また，いずれの統計解析も有意水準 5\%で行った.

\section{5） キーパーの結晶粒度の観察}

結晶粒度の観察は, 鋳接前の未加工のキーパーおよび鋳 接した試料の鋳接後, 溶体化処理後, 硬化熱処理後のキー パー部分について行った．各キーパーは自動研磨機 ECOMET 3 (Buehler) を用いて, \# 340，\#400，\#600の $\mathrm{SiC}$ 紙研磨， $0.05 \mu \mathrm{m}$ のアルミナによるバフ研磨を行った のち，表面を飽和シュウ酸水溶液中で電圧 $7 \mathrm{~V}$, 電流 0.6 A で電解エッチングし, 光学顕微鏡にて観察した。

\section{III. 結 果}

\section{1. 硬さの測定結果}

1） $12 \%$ 金銀パラジウム合金

$12 \%$ 金銀パラジウム合金の鋳接と加熱処理に伴う硬さ の変化を図 2 に示す. 二元配置分散分析の結果，最終係留 温度の違いにより硬さに有意な差は認められなかった。一 方，熱処理条件の違いにより硬さは有意な差を示した。ま

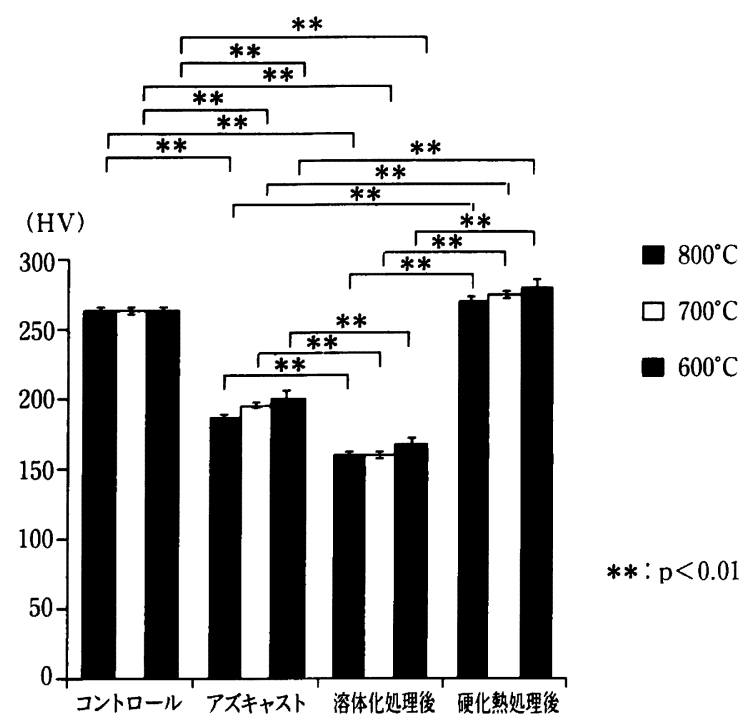

图 2 Effect of heat treatment on the hardness of gold-silver-palladium alloy 熱処理が硬さに及ほす影響 $12 \%$ 金銀パラジウム合金
た，係留温度と熱処理条件の 2 要因間には交互作用が認め られなかった. 多重比較検定の結果，鋳接後のアズキャス トの状態では $12 \%$ 金銀パラジウム合金の硬さはコント ロール (インゴット) の（HV：263）に比べ, 189.9〜 199.9 と有意に低下した $(\mathrm{p}<0.01)$. 溶体化処理後の試料 では硬さは 157.5〜166.1 となり，アズキャストの硬さに 比べ有意に低下した $(\mathrm{p}<0.01)$. 硬化熱処理後の試料で は $273.8 〜 281.3$ となり, 溶体化処理後の值に比べ有意に 増加した $(\mathrm{p}<0.01) .600,700$ および $800^{\circ} \mathrm{C}$ と係留温度 の異なる試料の間の比較では鋳造後, 溶体化処理後, 硬化 熱処理後のいずれの条件においても係留温度が低いほど硬 さは大きい傾向があったが，各温度間では有意差を示さな かった.

2) キーパー

(1) ハイコレックススリムキーパー

キーパーの鋳接と $12 \%$ 金銀パラジウム合金に対する熱 処理に伴うキーパーの硬さの変化を図 3 に示す. 二元配置 分散分析の結果, 最終係留温度の違いにより硬さに有意な 差は認められなかった。一方，熱処理条件の違いにより硬 さは有意な差を示した，また，係留温度と熱処理条件の 2 要因間には交互作用が認められなかった。多重比較検定の 結果，キーパーの硬さは非加熱のコントロール（HV： 246）に比へ，鋳接後に有意に低下した（ $\mathrm{p}<0.01 ）$.さら に，12\% 金銀パラジウム合金に対する溶体化処理後には 鋳接後の硬さに比べ有意に減少した $(\mathrm{p}<0.01)$ 。これに 引き続いて硬化熱処理を行うと硬さはわずかに変化した が，溶体化処理後の硬さと比べ有意差を示さなかった。

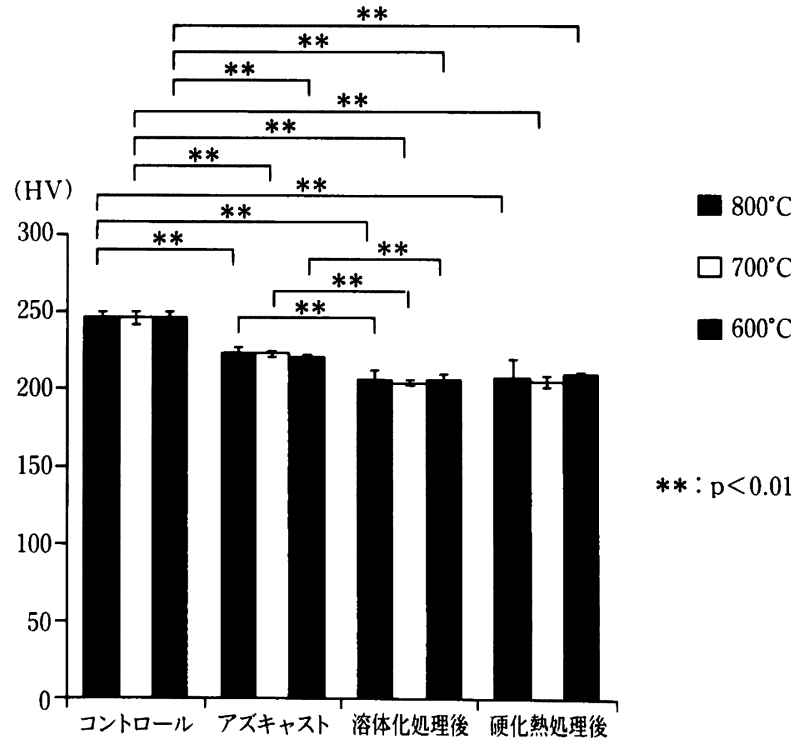

図 3 Effect of heat treatment on the hardness of keepers Hicorex slim keeper 熱処理が硬さに及ほす影饗 ハイコレックススリムキーパー 


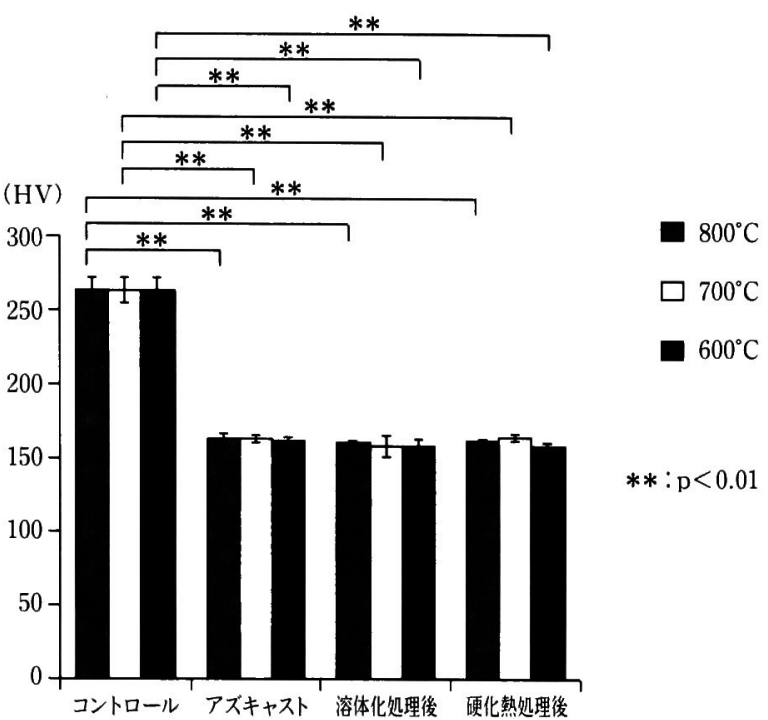

図 4 Effect of heat treatment on the hardness of keepers Magfit 600 keeper 熱処理が硬さに及ぼす影響 マグフィット 600 キーパー

600,700 および $800^{\circ} \mathrm{C}$ と係留温度の異なる試料の間の比 較では鋳造後, 溶体化処理後, 硬化熱処理後のいずれの条 件においても硬さに有意差を示さなかった.

$12 \%$ 金銀パラジウム合金の硬さと比べた場合, 非加熱 のキーパーは $12 \%$ 金銀パラジウム合金のインゴットより HVで 20 低い值を示していたが，鋳造後にはほほ同レべ ルとなり，溶体化処理後には金銀パラジウム合金よりも硬 く, 硬化熱処理後で低い值を示した.

(2) マグフィット 600 キーパー

キーパーの鋳接と $12 \%$ 金銀パラジウム合金に対する熱 処理に伴うキーパーの硬さの変化を図 4 に示す. 二元配置 分散分析の結果, 最終係留温度の違いにより硬さに有意な 差は認められなかった。一方, 熱処理条件の違いにより硬 さは有意な差を示した。また，係留温度と熱処理条件の 2 要因間には交互作用が認められなかった. 多重比較検定の 結果, キーパーの硬さは非加熱のコントロール (HV: 264）に比べ，鋳接後に有意に低下した（p<0.01）. しか し， $12 \%$ 金銀パラジウム合金に対する溶体化処理後, 硬 化熱処理後の硬さはわずかに変化したが，アズキャストの 硬さと比べ有意差を示さなかった， $600 ， 700^{\circ} \mathrm{C}$ おび $800^{\circ} \mathrm{C}$ と係留温度の異なる試料の間の比較では, 鋳造後, 溶体化処理後, 硬化熱処理後のいずれの条件においても硬 さに有意差を示さなかった.

$12 \%$ 金銀パラジウム合金の硬さと比べた場合，非加熱 のキーパーは $12 \%$ 金銀パラジウム合金のインゴットと同 レベルであったが, 鋳造後に低い值となり溶体化処理後に は金銀パラジウム合金と同レベル，硬化熱処理後では低い 値を示した。

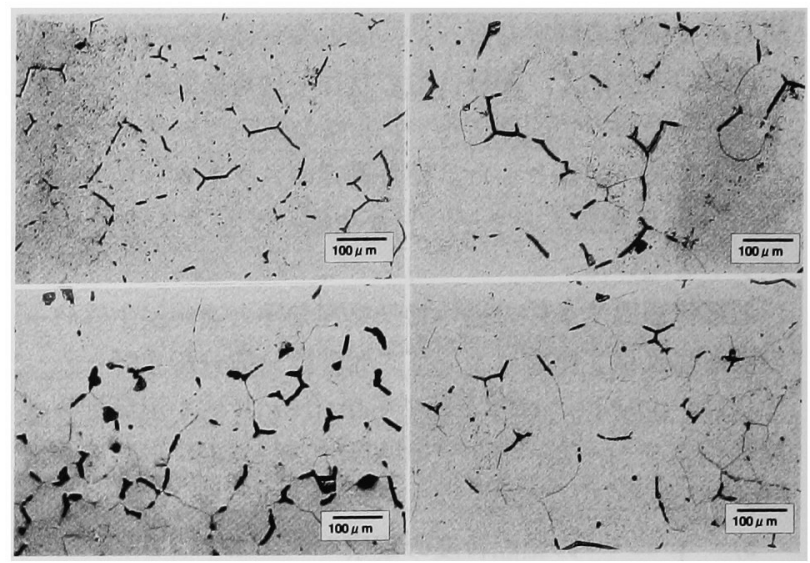

图 5 Microscopic findings of heat-treated keepers Hicorex slim keeper (mould temperature $: 600^{\circ} \mathrm{C}$ ) 熱処理後の金属組織像

ハイコレックススリムキーパー 最終係留温度 : $600^{\circ} \mathrm{C}$

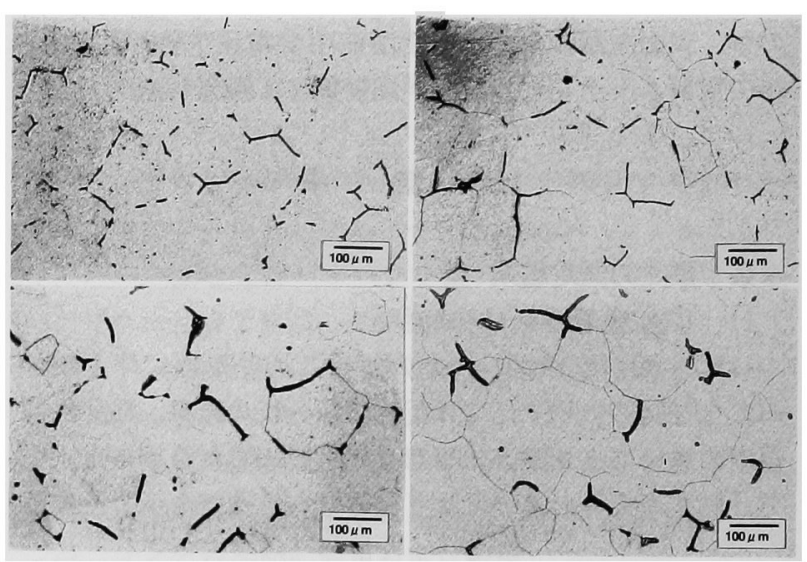

国 6 Microscopic findings of heat-treated keepers Hicorex slim keeper (mould temperature $: 800^{\circ} \mathrm{C}$ ) 熱処理後の金属組織像

ハイコレックススリムキーパー 最終係留温度 : $800^{\circ} \mathrm{C}$

2. キーパーの結晶粒度の観察結果

1) ハイコレックススリムキーパー

非加熱のコントロールの金属組織写真および加熱後の代 表例として, 最終係留温度 $600^{\circ} \mathrm{C}$ と $800^{\circ} \mathrm{C}$ における金属組 織写真を図 5,6 に示す.コントロールとした非加熱の キーパーでは，結晶粒は約 $100 \mu \mathrm{m}$ の粒径をした多角形で 粒界は不鮮明であった， $600 ， 700^{\circ} \mathrm{C}$ の場合，アズキャス トでは粒径が約 $100 \mu \mathrm{m}$ の結晶粒の間に径が $150 \mu \mathrm{m}$ 以上 の粗大な結晶粒が認められた，溶体化処理，硬化熱処理後 には粗大な結晶粒はさらに増加した。 $800^{\circ} \mathrm{C}$ 係留では 600 , $700^{\circ} \mathrm{C}$ 係留の場合に比べ，アズキャストでは粒径が 150 $\mu \mathrm{m}$ 以上へと成長し, 粗大化した結晶粒も増加した。さら に $800^{\circ} \mathrm{C}$ 係留の試料では溶体化処理, 硬化熱処理と熱処理 が進むにつれて粗大な結晶粒が増加し，結晶粒界が明瞭と 


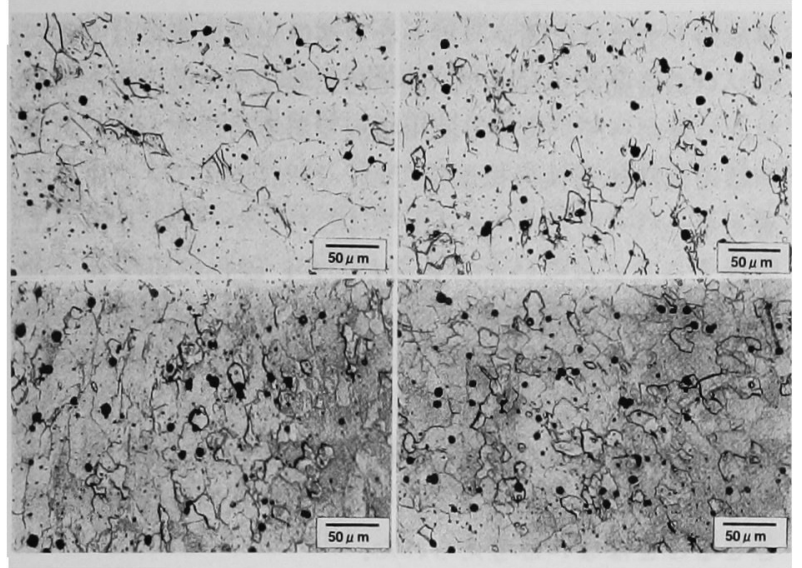

図 7 Microscopic findings of heat-treated keepers Magfit 600 keeper (mould temperature $: 600^{\circ} \mathrm{C}$ ) 熱処理後の金属組織像

マグフィット 600 キーパー

最終係留温度：600 $0^{\circ} \mathrm{C}$

なった．また， $600,700^{\circ} \mathrm{C}$ 係留の場合に比へ熱処理が進 むにつれて結晶粒はより粗大化し，それらが占める割合も 増加した。

2) マグフィット 600 キーパー

非加熱のコントロールの金属組織写真および加熱後の代 表例として, 最終係留温度 $600^{\circ} \mathrm{C}$ と $800^{\circ} \mathrm{C}$ における金属組 織写真を図 7,8 に示す.コントロールとした非加熱の キーパーでは結晶粒は約 $30 \mu \mathrm{m}$ の粒径をした多角形で粒 界は不鮮明であった. $600,700^{\circ} \mathrm{C}$ の場合, アズキャスト では粒径が約 $30 \mu \mathrm{m}$ の結晶粒の間に径がやや大きい結晶 粒が認められたが，ハイコレックススリムキーパーのよう な結晶粒の著しい成長は観察されなかった。溶体化処理, 硬化熱処理後にも大きな結晶粒は増加しなかったが，熱処 理が進むにつれて結晶粒界が明瞭となった. $800^{\circ} \mathrm{C}$ 係留で はアズキャストでは粒径が約 $50 \mu \mathrm{m}$ と成長し, 結晶粒界 が $600,700^{\circ} \mathrm{C}$ 係留の場合に比べ鮮明であった: さらに溶 体化処理, 硬化熱処理と熱処理が進むにつれて結晶粒界が より明瞭となり，エッチングに対する感受性が増している ことがうかがえた。

\section{IV. 考 察}

\section{1. キーパー材料ならびに実験方法について}

本実験において使用した磁性アタッチメント用キーパー は, 現在国内で入手できる 2 社の製品を選択した. マグ フィットシステムは現在小型のマグフィット Ex 600 と なっているが, キーパー素材は同一のものであることか ら，硬さ測定や結晶粒度の観察が容易な断面積の大きいマ グフィット 600 用キーパーを使用した。いずれのキーパー 素材も工業的に特に耐食性に優れたものとされる中, 高 $\mathrm{Cr}$ フェライト系ステンレス合金であるが, この合金は金

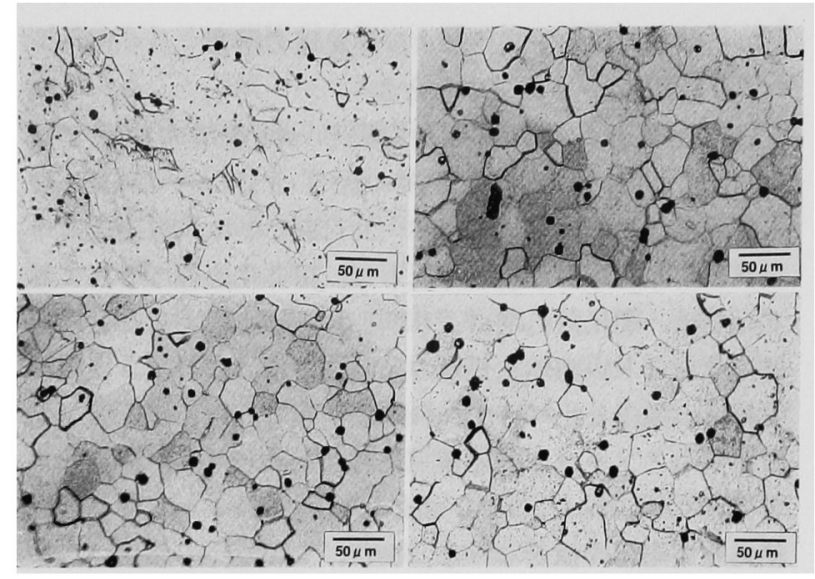

图 8 Microscopic findings of heat-treated keepers Magfit 600 keeper (mould temperature $: 800^{\circ} \mathrm{C}$ ) 熱処理後の金属組織像

マグフィット 600 キーパー

最終係留温度 : $800^{\circ} \mathrm{C}$

属組織と関連したいくつかの脆化現象が知られてい $ろ^{7 \sim 9)}$. このなかで比較的短時間で発生し, 歯科鋳造過程 で遭遇する温度領域に関係するものとして，400〜 $500^{\circ} \mathrm{C}$ に保持されたとき生じる $475^{\circ} \mathrm{C}$ 脆化, $600^{\circ} \mathrm{C}$ 以上で生じる $\sigma$ 相脆化, $900 \sim 1,000^{\circ} \mathrm{C}$ からの急冷で生じる高温脆化が あげられる、キーパーは冷し金となることから，鋳接後た だちに急冷せず室温まで放冷することが推奨されており， 今回の研究でも放冷していることから高温脆化は生じてい ないと考えられる.さらに, 高 $\mathrm{Cr}$ フェライト系ステンレ ス合金は粒成長を起こしやすく，結晶粒の粗大化は一般に 勒性の低下をもたらすとされている。森戸ら ${ }^{10}$ は，同時に 口腔内に装着された磁石構造体とキーパーを観察し, キー パー材料のみに肉眼的変化が生じたことを報告し，技工操 作に伴う加熱が影響しているものとしている.さらに長谷

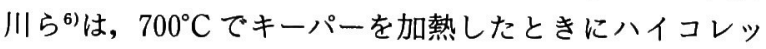
クス用キーパーにヌープ硬さの減少と結晶の成長が生じた ことを報告している。しかし，この報告では $\sigma$ 相が出現

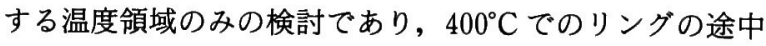
係留や溶融した鋳造合金との接触時の高温の影響について は不明である．また，鋳造合金に対する溶体化処理，硬化 熱処理による繰り返し加熱の影響も明らかではない.そこ で, 本研究においては実際の鋳接行程に従って試料を製作 して硬さと結晶について検討することとした，今回の研究 では，より多くの因子が関係すると考えられるキーパー材 と鋳造合金の接合界面での両金属の接触による影響を除外 し，鋳接，熱処理行程がそれぞれの金属に及ほす影響を検 討するため, 硬さ測定ならびに結晶の観察は接合界面から 離れた場所を選択した。 


\section{2. 硬さに及ぼす鋳接および熱処理の影腤}

1) $12 \%$ 金銀パラジウム合金

$12 \%$ 金銀パラジウム合金の硬さは鋳接後の状態では 189.9 199.9, 溶体化処理後の硬さは 157.5 166.1, 硬 化熱処理後の試料では $273.8 \sim 281.3$ となり, 鋳造後にイ ンゴットの状態から硬さが低下し，溶体化処理でさらに低 下した後, 硬化熱処理により増加し, 硬さは硬化熱処理, アズキャスト, 溶体化処理の順となった。この硬さの值は 中村 ${ }^{11)}$ の報告と比べいずれの処理状態でもいくぶん大きな 值を示し, メーカー表示值（溶体化処理後 146, 硬化熱処 理後 280）に比べた場合, 溶体化処理でわずかに硬く硬化 熱処理で同等の值となった。 また，大和屋 ${ }^{12)}$ の報告（溶体 化処理後 143, 硬化熱処理後 271), 中村 ${ }^{13}$ )の報告（溶体化 処理後 165, 硬化熱処理後 295）と比べいずれも近似した ものであった. $12 \%$ 金銀パラジウム合金のアズキャスト， 溶体化処理, 硬化熱処理における硬さの值からキーパーと 鋳接された状態であっても所定の熱処理効果が得られたも のと考えられた。

$$
\begin{aligned}
& \text { 2) キーパー } \\
& \text { (1) ハイコレックススリムキーパー }
\end{aligned}
$$$$
\text { キーパーの硬さはコントロール（HV：246）に比べ鋳 }
$$
接後に低下（HV：220～223）し，12\% 金銀パラジウム合 金に対する溶体化処理後にさらに減少 (HV：205～207) した.これに引き続いて行った硬化熱処理後にはわずかに 変化した（HV：206〜210）が, 溶体化処理後と比べ有意 差を示さなかった，また， $600 ， 700$, および $800^{\circ} \mathrm{C}$ と係留 温度の異なる試料の間の比較では鋳造後, 溶体化処理後, 硬化熱処理後のいずれの条件においても硬さに有意差を示 さなかった. 長谷川ら ${ }^{6}$ の報告（コントロール：267, $700^{\circ} \mathrm{C} 15$ 分加熱後： $213,700^{\circ} \mathrm{C} 30$ 分加熱後 222）と比較 すると, 初期状態 (コントロール) ではわずかに硬さの值 が低く，鋳接後ではわずかに高い值を示したがいずれも近 似した値であった。 長谷川ら ${ }^{6)}$ 報告では, $700^{\circ} \mathrm{C} 15$ 分加 熱より 30 分加熱のほうが硬さが増加しており, 今回のア ズキャストの值は 30 分加熱の值により近似していた. 長 谷川らの研究では, $700^{\circ} \mathrm{C}$ の加熱であったため $475^{\circ} \mathrm{C}$ 脆化 は起こらず，さらに短時間であったため $\sigma$ 相脆化による 影響も顕著には表れなかったと考えられる．このことが $200,400^{\circ} \mathrm{C} て ゙$ 係留した後最終係留をして鋳造した今回の 研究と硬さに相違があった一因と考えられた．溶体化処理 後, 硬化熱処理後の值は長谷川ら ${ }^{6)}$ の報告における繰り返 し加熱後の值と近似していた. 高 $\mathrm{Cr}$ フェライト系ステン レス合金に対する $600 \sim 800^{\circ} \mathrm{C}$ の後熱処理は靭性を劣化さ せるとされており ${ }^{8)}$ ，長谷川ら ${ }^{6)}$ の繰り返し加熱や本研究 における溶体化処理による $700^{\circ} \mathrm{C} て ゙ の$ 再加熱の影響と加熱 後の結晶粒の粗大化が硬さ低下の原因になったと考えられ た.

$12 \%$ 金銀パラジウム合金の硬さと比べた場合, アズ
43 巻 5 号（1999）

キャストではほほ同レベルとなり溶体化処理後には金銀パ ラジウム合金よりも硬く, 硬化熱処理後では低い值を示し た、したがって，実際の使用状況であるアスキャストある いは硬化熱処理後の根面板では，12\% 金銀パラジウム合 金とキーパーはアズキャストではどちらか一方が片寄って 摩耗することはないと考えられたが，硬化熱処理後では キーパーがやや傷付きやすいと考えられた．さらに磁石構 造体との接触を考えた場合, 非加熱状態である磁石構造体 吸着面はコントロールの硬さと同一とみなすことができ, 鋳造後, 熱処理後の硬さと比較すると非加熱の磁石構造体 のほうがいくぶん硬いことから，磁石構造体吸着面を摩耗 させることはないと考えられた。

(2) マグフィット 600 キーパー

キーパーの硬さは非加熱の場合（HV：264）に比べ, 鋳接後に有意に低下した。しかし，12\% 金銀パラジウム 合金に対する溶体化処理後, 硬化熱処理後の硬さはほとん ど変化しなかった. 600,700 , および $800^{\circ} \mathrm{C}$ と係留温度の 異なる試料の間の比較では鋳造後, 溶体化処理後, 硬化熱 処理後のいずれの条件においても硬さに有意差を示さな かった. 長谷川ら ${ }^{6}$ の報告（コントロール：246, $700^{\circ} \mathrm{C} 15$ 分加熱後：224, $700^{\circ} \mathrm{C} 30$ 分加熱後 268） と比較すると, 初期状態（コントロール）ではわずかに硬く鋳接後では低 い値を示した。 また，溶体化処理後，硬化熱処理後の値は 長谷川ら ${ }^{6}$ の報告における繰り返し加熱後の価 244 と比へ 160 前後と低い值を示した. 長谷川ら ${ }^{6)}$ の報告より，加熱 後の硬さが低い值を示したにもかかわらず結晶粒度には著 しい粗大化は観察されず硬さが低下した原因については， 金属組織に対するより詳細な分析により解明する必要があ ると考えられた。

$12 \%$ 金銀パラジウム合金の硬さと比べた場合, 溶体化 処理後ではほほ同レベルであったもののアズキャスト，硬 化熱処理後では $12 \%$ 金銀パラジウム合金より低い值を示 した．したがって，実際の使用状況であるアズキャストあ るいは硬化熱処理後の根面板では, $12 \%$ 金銀パラジウム 合金と加熱後のキーパーが接触した場合にキーパーのほう がわずかではあるが傷付きやすいと考えられた。さらに磁 石構造体との接触を考えた場合, 非加熱状態である磁石構 造体吸着面はコントロールの硬さと同一とみなすことがて き, 鋳造後, 熱処理後の硬さと比較すると非加熱の磁石構 造体のほうがいくぶん硬いことから, 磁石構造体吸着面を 摩耗させることはないと考えられた。

\section{3. キーパーの結晶粒度}

1) ハイコレックススリムキーパー

非加熱のコントロールでは, 長谷川ら に, 結晶粒は約 $100 \mu \mathrm{m}$ の粒径をした多角形で粒界は不鮮 明であった.アズキャストでは $600,700^{\circ} \mathrm{C}$ の場合, 長谷川 ら ${ }^{6}$ の報告のように，ほとんどすべての結晶粒が $300 〜 400$ 
$\mu \mathrm{m}$ まで成長することはなく，粒径が約 $100 \mu \mathrm{m}$ の結晶粒 の間に径が $200 \mu \mathrm{m}$ 内外の粗大な結晶粒が観察された。溶 体化処理, 硬化熱処理後には粗大な結晶粒はいくぶん成長 するとともにその割合は増加した。これに対し $800^{\circ} \mathrm{C}$ 係留 では $600,700^{\circ} \mathrm{C}$ 係留の場合に比べ, アズキャストでは粒 径が $150 \mu \mathrm{m}$ 以上へと成長した結晶粒が増加した。さらに $800^{\circ} \mathrm{C}$ 係留の試料では溶体化処理, 硬化熱処理と熱処理が 進むにつれて, 粗大な結晶粒が増加するとともに結晶粒界 が明瞭となり, 硬化熱処理後の試料では長谷川ら ${ }^{6}$ の報告 と同様 300〜 400 $\mu \mathrm{m}$ まで成長した結晶粒が観察された。 また, $600,700^{\circ} \mathrm{C}$ 係留の場合に比べ, 熱処理が進むにつ れて結晶粒はより粗大化し, 大きな結晶が占める割合も増 加した. ハイコレックススリムキーパーのような高 $\mathrm{Cr}$ フェライト系ステンレス合金は粒成長を起こしやすいとさ れており ${ }^{8)}$, 今回の観察結果も同様の所見を示した. 結晶 粒度と靯性を直接関係づけるのは難しいとされるが, 結晶 .粒の粗大化は一般に勒性の低下をもたらすとされる から，キーパー加熱後に硬さが減少した原因の 1 つに結晶 粒の粗大化があると考えられた。ささらに結晶粒界には, エッチングされやすい部分が太い線として表れ，粒界部に 腐食感受性の高い部分があることが推察された。

2) マグフィット 600 キーパー

非加熱のコントロールのキーパーでは, 長谷川ら6)の報 告と同様に, 結晶粒は約 $30 \mu \mathrm{m}$ の粒径で粒界の明瞭な多 角形を示す部分もあったが全般に粒界は不鮮明であった。 $600,700^{\circ} \mathrm{C}$ の場合, アズキャストでは約 $30 \mu \mathrm{m}$ の粒径の 結晶粒の間に径がやや大きいものが認められ, 粒界もより 鮮明になったが，ハイコレックススリムキーパーのような 結晶粒の著しい成長は観察されなかった. 溶体化処理, 硬 化熱処理後にも結晶粒の成長は観察されなかったが, 熱処 理が進むにつれて結晶粒界が明瞭となった. $800^{\circ} \mathrm{C}$ 係留で は,アズキャストでは粒径が約 $40 \mu \mathrm{m}$ と成長し, 結晶粒 界が $600,700^{\circ} \mathrm{C}$ 係留の場合に比べ鮮明に表れた。さらに 溶体化処理, 硬化熱処理と熱処理が進むにつれて結晶粒界 がより明瞭となり，エッチングに対する感受性が増してい ることがうかがえたが, 結晶粒の大きさや粗大な結晶の割 合の増加はハイコレックススリムキーパーと異なり観察さ れなかった. 長谷川ら ${ }^{6)}$ の報告では $700^{\circ} \mathrm{C}$ 加熱後の組織で も結晶粒界が不鮮明のままであったが, 本研究では結晶粒 界が鋳造, 加熱後により鮮明となっており，600〜 $800^{\circ} \mathrm{C}$ で熱処理を行うと粒界への炭窒化物の析出により靱性が低 下するとされていること采から，この影響で硬さが低下し たと考えられた。

\section{4. 鋳接, 熱処理の臨床応用上の意義}

磁性アタッチメントでは, 磁石構造体とキーパーがきち んと密着していないと所定の吸引力を発揮することができ ないため, キーパーと磁石構造体の吸着面は高精度の適合
が求められる．磁性合金による根面板の鋳造では，この適 合を得ることが難しいため，現在では一般的に既成のキー パーを何らかの方法で根面板に組み込む方式が主流であ る. 本邦では磁性アタッチメントのキーパーは, 現在ほと んどが歯科用合金と鋳接して使用されている ${ }^{14,15)}$ が，セメ ント合着法やねじで固定する方法も紹介されてい る ${ }^{16 ~ 19)}$. 鋳接法は術式が簡単であり, キーパーの脱落も 稀であることから広く用いられているが, 鋳接に伴う加熱 は本来そのような加熱を想定していないステンレス鋼に とっては苛酷な条件であり, 矯正用のステンレス線の蠟着 における加熱の研究20,21)では, ステンレス線は蠟着過程で $400^{\circ} \mathrm{C}$ 以上に加熱されると耐食性が低下すると報告されて いる. 本研究で使用した磁性アタッチメントのキーパー は,これらのステンレス合金に比べ耐食性に優れた高 $\mathrm{Cr}$ フェライト系ステンレス合金を使用しているが, 鋳接に伴 いその特性が変化する可能性がある. 本研究の結果から, いずれのキーパーも最終係留温度が高い試料のほうが結晶 粒界が鮮明となり,さらに粒界に析出物の観察されるもの もあった.このことは, 腐食感受性が増加したことをうか がわせるものであった．この結果から，鋳接にあたっては 鋳造精度を損ねない範囲で高温係留を避けるべきであると 考えられた。

$12 \%$ 金銀パラジウム合金の熱処理に伴う加熱は，ハイ コレックススリムキーパーでは硬さの低下を生じた。ま た，いずれのキーパーも熱処理が進むにつれ結晶粒界が鮮 明となり，粒界に析出物も観察されるようになった，中 村 ${ }^{11}$ は, これらの熱処理を行った $12 \%$ 金銀パラジウム合 金の疲労強度の検討のなかで，メーカー指示通りに硬化熱 処理を行ってもアズキャストの状態以上の耐久性が得られ ないと報告している，この点とあわせて考えると, キー パーを鋳接した根面板はアズキャストの状態で用いること が, 熱履歴に伴う悪影響を回避するうえで重要であること が示唆された.さらに, 耐食性に対する危惧を回避するた めには, キーパーの加熱を避けることが必要であり, キー パーが脱落しないようなセメント合着法や可撤式キー パー22 25)が有効であり，今後は鋳接法に匹敵する程度に 技工操作の簡便な方法が開発されることが必要になると考 えられた。

\section{V. 結 論}

鋳接ならびに鋳造合金に対する熱処理が磁性アタッチメ ントのキーパーに及ほす影響を検討することを目的とし， $12 \%$ 金銀パラジウム合金で鋳接したキーパーの鋳造後, 溶体化処理後, 硬化熱処理後のビッカース硬さの測定なら びにキーパーの金属結晶組織の観察を行い，以下の結論を 得た。

1. ハイコレックススリムキーパーの硬さは, 加熱して 
いない未処理のものに比べ鋳接後, $12 \%$ 金銀パラジウム 合金に対する溶体化処理後において有意に減少したが，硬 化熱処理後には溶体化処理後と比べて変化を生じなかっ た。

2. マグフィット 600 キーパーの硬さは，加熱していな い末処理のものに比べ鋳接後において有意に減少したが, $12 \%$ 金銀パラジウム合金に対する溶体化処理後，硬化熱 処理後には変化を生じなかった。

3. ハイコレックススリムキーパーの金属組織の観察で は，コントロールの結晶粒径に比べ鋳接後に粗大な結晶粒 が出現し熱処理が進むとその割合はさらに増加した。 $800^{\circ} \mathrm{C}$ 係留の場合には， $600,700^{\circ} \mathrm{C}$ 係留の場合に比べ, 結 晶粒の成長が著明であり，結晶粒界もより鮮明であった。

4. マグフィット 600 キーパーの金属組織の観察では, コントロールの結晶粒径に比べ鋳接後に結晶粒がいくぶん 成長したが，ハイコレックススリムキーパーのような成長 は観察されなかった．溶体化処理後，硬化熱処理後にも大 きな結晶粒は増加しなかったが，熱処理が進むにつれて結 晶粒界が明瞭となった。 $800^{\circ} \mathrm{C}$ 係留の場合には, 600 , $700^{\circ} \mathrm{C}$ 係留の場合に比べ結晶粒界がより鮮明であった。

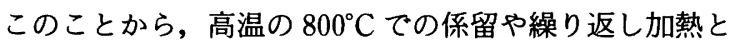
なる熱処理はキーパー材にとって好ましくないものであ り，鋳造操作上問題のない範囲で低い係留温度を用い，ア ズキャストで使用することが望ましいと考えられた。

本研究の一部は 76 th General Session of the IADR（平成 10 年 6 月 $24 \sim 27$ 日, ニース, フランス) において発表した。

\section{文献}

1) Okuno O, Ishikawa S, Iimuro FT et al. Development of sealed cup yoke type dental magnetic attachment. Dent Mater J $10: 172-184,1991$

2）田中貫信，本蔵義信，平沼謙二ほか。 サンドイッチ型磁性アタ ッチメントに関する臨床的検討. 補綴誌 $35 ： 599-608,1991$.

3）水谷 紘, 藍 稳. 磁性アタッチメントーその特性を生かし た臨床応用法一. QDT 16：91-102, 1991.

4）島田和広，平田順子，石川 晋ほか．鋳造リングの加熱媻留条 件や埋没材の違いがキーパーの酸化膜形成に及ほす影製。日磁 歯誌 $3: 69-70,1994$.

5）中村和夫，水谷 紘，藍 稔ほか。磁性合金の補経領域にお ける応用 第 8 報 ネオジム磁石を応用した磁性アタッチメン ト. 補経誌 $39 \cdot 94$ 回特別号：139, 1995.

6）長谷川欽司，森戸光彦，平野 進ほか。磁性アタッチメント用 キーパーの加熱と酸処理による影響について，日磁曾誌 $5: 51$ -
$57,1996$.

7）溶接学会編，溶接・接合便覽，東京：丸善, 1990 .

8）ステンレス協会編．ステンレス䤡便覧第 3 版，東京：日刊工 業新聞社, 1995.

9）大山 正，森田 茂，吉武進也. ステンレスのおはなし，東 京：日本規格協会, 1990.

10）森戸光彦，長谷川欽司，平野 進ほか，磁性アタッチメント用 キーパーの臨床的観察. 日磁㐘誌 $5: 45-50,1996$.

11） 中村英雄．金銀パラジウム合金鋳造体の疲労強度に及ほす熱処 理の影響. 歯材器 $16: 141-154,1997$.

12）大和屋文彦，中村健吾，後藤真一，鋳造用銀パラジウム合金の 諸性質に及ほす金添加の影響. 歯材器 4:730-753, 1985.

13）中村健吾。銀・パラジウム・銅合金の諸性質ＤE $75 ： 14-24$, 1975 .

14）田中貴信. 磁性アタッチメント，磁石を利用した新しい補緅治 療, 東京：医歯薬出版, 1992.

15）水谷 紘, 石幡伸雄, 中村和夫. 藍 稔監修. 磁性アタッチ メントを用いた部分床義歯，東京：クインテッセンス出版 1994.

16) Gillings BRD. Magnetic retention for the overdenture. In : Brewer AA, Morrow RM, editors, Overdentures 2 nd ed 364 397, St. Louis : C.V. Mosby, 1980.

17) Gillings BRD. Overdenture with magnetic attachments. Dent Clin North Am $34: 683-709,1990$.

18）服部正巳，浅井治彦，甲藤克彦ほか，在宅歯科診療を考虑した キーパーの接着固定法の検討. 日磁菌誌 $6: 50-56,1997$.

19）石田 隆，水谷憲彦，中村好徳ほか. キーパーハウジングを用 いた磁性アタッチメントキーパーのセメント固定法に関する実 験的検討. 補緅誌 $42 \cdot 99$ 回特別号 : 100, 1998.

20) Berge M, Gjerdet NR, Erichsen ES. Corrosion of silver soldered orthodontic wires. Acta Odontol Scand 40:75-79, 1982.

21) Gjerdet NR, Hero $H$. Metal release from heat-treated orthodontic archwires. Acta Odontol Scand $45:$ 409-414, 1987.

22）中村和夫，石川 晋, 藍 稔ほか. MRI 対策としてのキーパ 一可撤法の検討. 日磁歯誌 1:71-75, 1992.

23) Masumi $\mathrm{S}$, Nagatomi $\mathrm{K}$, Miyake $\mathrm{S}$ et al. Removable magnetic dental attachment that permits magnetic resonance imaging. J Prosthet Dent. 68:698-701, 1992.

24）大川周治，田嶋英明，赤川安正ほか．磁性アタッチメントの可 撤式キーパーに関する一考案一MRI 対策として一，日磁歯誌 $2: 37-42,1993$.

25）䲅見進一，小座本まゆみ，城戸寛史ほか．既成キーパーを利用 した可撤式機構の検討. 日磁歯誌 $3: 30-35,1994$

著者連絡先：中村 和夫

T113-8549 東京都文京区湯島 1-5-45

TEL • FAX 03-5803-5516 